\title{
Neonatal role of milk folate-binding protein: studies on the course of digestion of goat's milk folate binder in the 6-d-old kid
}

\author{
By D. N. SALTER AND A. MOWLEM \\ National Institute for Research in Dairying, Shinfield, Reading, \\ Berkshire RG2 9AT
}

(Received 2 November 1982 - Accepted 20 May 1983)

\begin{abstract}
1. Groups of kids were reared from birth to $5 \mathrm{~d}$ on goat's milk. On the 6 th day five of the kids received by bottle a morning feed of goat's milk with $\left[{ }^{3} \mathrm{H}\right]$ folic acid added to saturate the folate-binding proteins (FBP) (Expt 1); three kids received raw goat's milk containing only the endogenous folate and hence a large surplus folate-binding capacity (FBC) (Expt 2). The contents of the stomach, duodenum, jejunum and ileum were recovered by washing out $1.5 \mathrm{~h}$ after feeding (Expt 1) or at $0.5,1$ and $3.5 \mathrm{~h}$ after feeding (Expt 2).

2. Recovery of [ ${ }^{3} \mathrm{H}$ ] folic acid $1.5 \mathrm{~h}$ after feeding (Expt 1 ) in all segments was $58.4 \%$, mainly in a soluble form, most of this being in the stomach $(37.0 \%)$ and ileum $(14.3 \%)$. No surplus FBC was found in any gut segment. Sephadex G-75 chromatography of the soluble fractions of the contents of the various gut segments showed that $\left[{ }^{3} \mathrm{H}\right]$ folic acid remained bound to FBP throughout the stomach and small intestine. The bound [ $\left.{ }^{3} \mathrm{H}\right]$ folic acid exhibited a molecular weight of 81000 in stomach contents, similar to that in the milk feed, presumably representing an aggregated form of the FBP, whereas in the intestinal contents its molecular weight was 39000 indicating dissociation to monomer due to dilution in the recovery process.

3. In Expt 2, the total recovery of free FBP in all four gut segments was 67,54 and $23 \%$ respectively at 0.5 , 1 and $3.5 \mathrm{~h}$ after the milk feed, and the distribution of FBP along the gut at $1 \mathrm{~h}$ was similar to that of $\left[{ }^{3} \mathrm{H}\right]$ folic acid-labelled FBP at $1.5 \mathrm{~h}$ in Expt 1. In mature goat's milk the endogenous 5-methyltetrahydrofolate was shown to be associated with species of molecular weight 80000 and 38000 .

4. The results indicate that goat's-milk FBP is relatively resistant to digestion by gastric and intestinal enzymes in vivo in the kid and survives along the length of the small intestine.

5. The implications of the findings are discussed in relation to the possible influence of FBP on uptake of folate by mucosal cells and their relevance to neonatal folate nutrition.
\end{abstract}

Although folate-binding proteins (FBP) are now known to exist in a wide range of tissues and body fluids, including serum (Waxman \& Schreiber, 1973), leucocytes (Rothenberg, 1970), intestinal epithelium (Leslie \& Rowe, 1972), kidney (Kamen \& Caston, 1974), liver (Zamierowski \& Wagner, 1977) and choroid plexus (Spector, 1977), they were first detected in milk. Ghitis (1967) demonstrated the presence of folate-binding substances in cow's milk and they were subsequently separated and identified as proteins in both cow's and human milk (Ford et al. 1969). The proteins have been successfully isolated and characterized from cow's milk (Salter et al. 1972, 1981), goat's milk (Rubinoff et al. 1977) and human milk (Hansen et al. 1977) but the physiological role of these milk binders has remained uncertain. Ford (1974) suggested that in milk the FBP may act initially in the mammary gland as a trapping agent to accumulate folate from blood plasma into milk, but after ingestion by the young animal it could assist absorption of folate by preventing its uptake by intestinal bacteria and might also directly promote absorption of folate across the intestinal mucosa. In vitro studies (Ford, 1974) showed that folate bound to milk FBP was not taken up by folate-requiring gut bacteria, but no evidence of a direct role in mucosal absorption has been demonstrated until recently (Colman et al. 1981) when it was shown that uptake of folate by rat intestinal cells in vitro was greater when it was bound to protein in whole goat's milk. The problem remains that in vitro digestion of the FBP by pepsin and trypsin destroyed the binding activity (Ford, 1974), raising the question whether in vivo sufficient FBP survives gastric and duodenal digestion to be effective in the small intestine. The present work was therefore undertaken to study, in two experiments, first, the course of digestion 
of goat's-milk FBP saturated with folate and the extent of survival of protein-bound folate, and second, the survival of unbound FBP in the gastrointestinal tract of the kid.

\section{EXPERIMENTAL \\ Kids and milk-feeding}

Expt 1. Five male kids from the Institute herd of pedigree British Saanen goats were used. For the first $3 \mathrm{~d}$ after parturition they were suckled by their dams and on days 4 and 5 they were bottle-fed from a bulk stock of raw goat's milk. For the experiment $250 \mu \mathrm{Ci}$ $\left[3^{\prime}, 5^{\prime}, 7,9-{ }^{3} \mathrm{H}\right]$ folic acid (potassium salt, specific activity $90 \mu \mathrm{Ci} / \mu \mathrm{g}$; Amersham International, Amersham, Bucks) and $400 \mu \mathrm{g}$ folic acid carrier were added to 2.51 of the bulk stock milk. This weight of folic acid was calculated exactly to saturate the excess free binding capacity of the milk FBP. The labelled milk was then divided into individual portions of about $400 \mathrm{ml}$ each and stored at $-20^{\circ}$ until used. For each experiment, a kid at $6 \mathrm{~d}$ post partum was given a measured quantity of the radioactive goat's milk $(300-400 \mathrm{ml})$ by bottle. Experiments were performed at approximately weekly intervals, each time on a different kid.

Expt 2. Three male kids were reared to $6 \mathrm{~d}$ as in Expt 1 . On the 6 th day each kid received a measured morning feed $(190-300 \mathrm{ml})$ from the bulk stock of raw goat's milk containing only the endogenous folate. In this milk the FBP was mainly in the unbound form.

\section{Removal of gut contents}

Expt 1 . The gut contents were recovered $1.5 \mathrm{~h}$ after the kid had consumed the radioactive milk by washing out under anaesthesia in order to obtain complete recovery with minimal contamination with mucosal debris. Each kid was given $150 \mathrm{mg}$ sodium pentobarbitone by injection into the jugular vein; the viscera were rapidly exposed; the gut ligated into four segments corresponding to stomach, duodenum, jejunum and ileum; and cannulas inserted into proximal and distal ends of each segment. A measured volume of isotonic saline $(9 \mathrm{~g}$ sodium chloride/1) at $37^{\circ}$ was passed through each segment by means of the proximal cannula until washings recovered at the distal cannula ran clear.

Expt 2. Three kids were anaesthetized, one at $0.5 \mathrm{~h}$, a second at $1 \mathrm{~h}$ and the third at $3.5 \mathrm{~h}$ after the test meal, and their gut contents washed out as described previously.

\section{Analysis of gut contents and milk}

Gut contents diluted with saline were centrifuged at $30000 \mathrm{~g}$ at $4^{\circ}$ for $20 \mathrm{~min}$ (High Speed 18; MSE, Crawley, Sussex) immediately after collection. The fat layer was removed and the samples centrifuged again at $40000 \mathrm{~g}$ for $2 \mathrm{~h}$. Sedimented material was stored in isotonic saline at $-20^{\circ}$ until analysed. A portion of the labelled goat's milk was similarly treated to separate fat and micellar caseins from whey. The clear supernatant fractions were passed through a membrane filter $(0.45 \mu \mathrm{m}$ pore; Amicon, High Wycombe, Bucks $)$ and $5 \mathrm{ml}$ filtrate passed down a $320 \times 26 \mathrm{~mm}$ column of Sephadex gel G-75 (Pharmacia (Great Britain) Ltd, Hounslow, Middlesex) eluted with buffer at $\mathrm{pH} 7.2$ containing $0.15 \mathrm{M}-\mathrm{NaCl}$ and $0.02 \mathrm{M}-$ sodium phosphate (buffer $A)$ to which had been added 2-mercaptoethanol $(0 \cdot 2 \mathrm{ml} / \mathrm{l})$. Effluent fractions $\left(3 \mathrm{ml}\right.$ each) were collected, analysed for $\left[{ }^{3} \mathrm{H}\right]$ folate and monitored for protein content by measurement of absorbance at $280 \mathrm{~nm}$ (Unicam SP8-100 spectrophotometer).

\section{Determination of radioactive folate}

Radioactive folate was monitored by digesting $1 \mathrm{ml}$ of each column fraction or gut contents supernatant with $1 \mathrm{ml} 1 \mathrm{~m}$-hyamine hydroxide (Nuclear Enterprises Ltd, Sighthill, Edinburgh), neutralizing with $0.5 \mathrm{ml}$ citric acid $(12 \mathrm{~g} / 1)$ and suspending in $10 \mathrm{ml}$ scintillant (Instagel; Packard Instrument Co Inc, Illinois). Samples were then counted in a Packard 


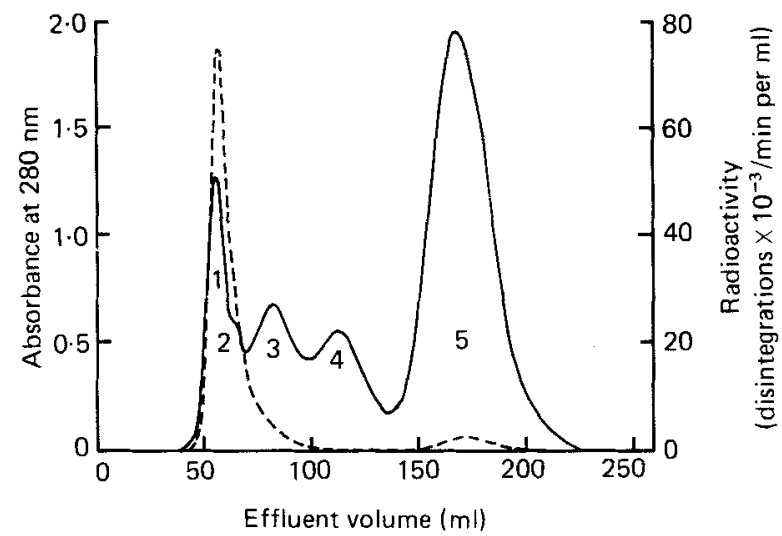

Fig. 1. Sehadex G-75 chromatography of goat's milk whey saturated with $\left[3^{\prime}, 5^{\prime}, 7,9-{ }^{3} \mathrm{H}\right]$ folic acid. Goat's milk saturated with the radioactive folic acid was centrifuged to remove fat and micellar casein and a $5 \mathrm{ml}$ sample analysed on a Sephadex G-75 column using a buffer containing $0.15 \mathrm{M}$-sodium chloride, $0.02 \mathrm{M}$-sodium phosphate, $\mathrm{pH} 7.2$, 2-mercaptoethanol $(0.2 \mathrm{ml} / 1) .(---),\left[{ }^{3} \mathrm{H}\right]$ folic acid; ( -$)$, absorbance at $280 \mathrm{~nm}$.

B2450 Tricarb liquid-scintillation spectrometer, with external standardization of counting efficiency. The radioactivity of sedimented material from the gut contents was measured by digesting $0.5 \mathrm{ml}$ samples of the homogenized suspensions with $1 \mathrm{ml}$ M-hyamine hydroxide in methanol, neutralizing and counting as for soluble fractions.

\section{Estimation of molecular weight}

Molecular weights of folate complexes were estimated from their elution volumes when run on the Sephadex G-75 column, by calibration of the column with standard proteins as described by Andrews (1964).

\section{Measurement of folate-binding capacity $(F B C)$}

The method used was adapted from that described by Ford et al. (1972). To four samples of each gut contents supernatant fraction or homogenized sediment in saline $(0 \cdot 2,0 \cdot 5,0 \cdot 8$ and $1.0 \mathrm{ml}$ ), adjusted to $\mathrm{pH} 7.2$ if necessary, was added $0.1 \mu \mathrm{Ci}(160 \mathrm{ng})^{3} \mathrm{H}$-labelled folic acid (sufficient to saturate the total binding capacity of $1 \mathrm{ml}$ of the original milk). The samples were then dialysed for $48 \mathrm{~h}$ against eight successive changes of $100 \mathrm{ml}$ buffer $A$ to which was added ascorbic acid $(200 \mathrm{mg} / \mathrm{l})$ and their ${ }^{3} \mathrm{H}$ content measured. Since the endogenous folate, 5-methyltetrahydrofolic acid, is less strongly bound to FBP than is folic acid (Waxman, 1977) it is displayed by $\left[{ }^{3} \mathrm{H}\right]$ folic acid in the course of this assay, which is therefore a measure of total FBC.

\section{Microbiological assay of total folate}

Folic acid activity was measured microbiologically with Lactobacillus casei, using an adaptation of the method of Herbert (1961) as described by Ford et al. (1969).

\section{RESULTS \\ Expt 1}

Form of protein-bound folate in goat's milk saturated with folic acid. When a sample of the whey produced by centrifugation of goat's milk was analysed by Sephadex gel G-75 chromatography (Ford et al. 1969) it was separated into a number of protein fractions approximating to soluble caseins, serum albumin, $\beta$-lactoglobulin and $\alpha$-lactalbumin (peaks 1-4 respectively, Fig. 1) and low-molecular-weight substances (peak 5, Fig. 1). More than 
Table 1. Recovery of $\left[{ }^{3} \mathrm{H}\right]$ folic acid $(\%)$ in the gut contents of 6-d-old kids 1.5 h after consuming a feed of goat's milk saturated with [ $\left.{ }^{3} \mathrm{H}\right]$ folic acid

(Mean values with their standard errors for five kids. The volume of milk consumed was 347 (SE 22) $\mathrm{ml}$ and its total folate content was 57 (SE 3.6) $\mu \mathrm{g}$ )

\begin{tabular}{|c|c|c|c|c|c|c|}
\hline \multirow[b]{3}{*}{ Gut segment } & \multicolumn{6}{|c|}{$\left[{ }^{3} \mathrm{H}\right]$ folic acid $(\%)$ recovered in gut contents } \\
\hline & \multicolumn{2}{|c|}{ Soluble fraction } & \multicolumn{2}{|c|}{ Insoluble fraction } & \multicolumn{2}{|c|}{ Total } \\
\hline & Mean & SE & Mean & SE & Mean & $\mathrm{SE}$ \\
\hline Stomach & $34 \cdot 4$ & 13.9 & $2 \cdot 6$ & 0.8 & $37 \cdot 0$ & 6.9 \\
\hline Duodenum & 0.2 & 0.07 & 0.05 & 0.03 & 0.25 & 0.06 \\
\hline Jejunum & $5 \cdot 3$ & $2 \cdot 3$ & $1 \cdot 3$ & 0.9 & $6 \cdot 6$ & 2.9 \\
\hline lleum & $12 \cdot 8$ & 3.8 & 1.7 & 0.5 & $14 \cdot 5$ & $4 \cdot 3$ \\
\hline Total for all segments & $52 \cdot 7$ & 5.9 & $5 \cdot 65$ & 0.9 & $58 \cdot 4$ & 6.0 \\
\hline
\end{tabular}

$95 \%$ of the $\left[{ }^{3} \mathrm{H}\right]$ folic acid was eluted in association with protein peak 1 , with an estimated molecular weight of 81000 ; the remainder was associated with peak 5 which coincided with the previously determined position of free folic acid.

Recovery of $\left[{ }^{3} \mathrm{H}\right]$ folic acid in gut contents. The proportion of the $\left[{ }^{3} \mathrm{H}\right]$ folic acid consumed in the milk that was recovered in the various segments of the gut, and its distribution between the soluble and insoluble fractions are shown in Table 1. The results show that over-all nearly $60 \%$ of the labelled folate was still present in the gut contents $1.5 \mathrm{~h}$ after feeding. Most of this (approximately $40 \%$ ) was in the stomach and the remainder was distributed throughout the small intestine, approximately $15 \%$ surviving into the ileum. The labelled folate was mainly in a dissolved form in all gut segments, ranging from $80 \%$ soluble in the duodenum to $93 \%$ soluble in the stomach.

Form of folate in contents of stomach and small intestine. The results of Sephadex G-75 chromatography of the soluble fraction of the contents of the stomach, duodenum, jejunum and ileum are shown for one kid in Fig. 2(a-d). Similar results were obtained with all five kids. The elution profile obtained with soluble stomach contents (Fig. $2 a$ ) was similar to that obtained by chromatography of the centrifuged goat's milk whey with three protein peaks corresponding to the major whey proteins. The ${ }^{3} \mathrm{H}$-labelled FBP was eluted close to the void volume with an estimated molecular weight of 81000 , similar to that in the whey. A small proportion of the ${ }^{3} \mathrm{H}(<10 \%)$ was eluted in a position corresponding to that of free folic acid. Sephadex analysis of the soluble fraction of duodenal contents (Fig. 2b) clearly showed evidence of digestion of the whey proteins, with an altered elution profile (absorbance at $280 \mathrm{~nm}$ ) no longer recognizable as that of whey and showing an increase in low-molecular-weight compounds at the expense of proteins. The labelled folate was mainly (85-90\%) eluted in fractions corresponding to a molecular weight of 39000 , but a small proportion of unbound folate was again observed. The results of Sephadex analysis of soluble fractions of the contents of the jejunum (Fig. 2c) and ileum (Fig. 2d) show the continuation of the processes of digestion with complete disappearance of identifiable whey proteins, but $\left[{ }^{3} \mathrm{H}\right]$ folic acid remained bound to proteins with peak activities corresponding to a molecular weight of approximately 39000 . An increase in the proportion of proteins completely excluded from the Sephadex gel (molecular weight $>100000$ ) was also observed, becoming most marked in the ileum.

Excess binding capacities of soluble and insoluble gut contents. When a further excess of $\left[{ }^{3} \mathrm{H}\right]$ folic acid was added to samples of the $\left[{ }^{3} \mathrm{H}\right]$ folic acid-labelled milk, supernatant fractions and sediment fractions of stomach, duodenum, jejunum and ileum, and the mixtures 

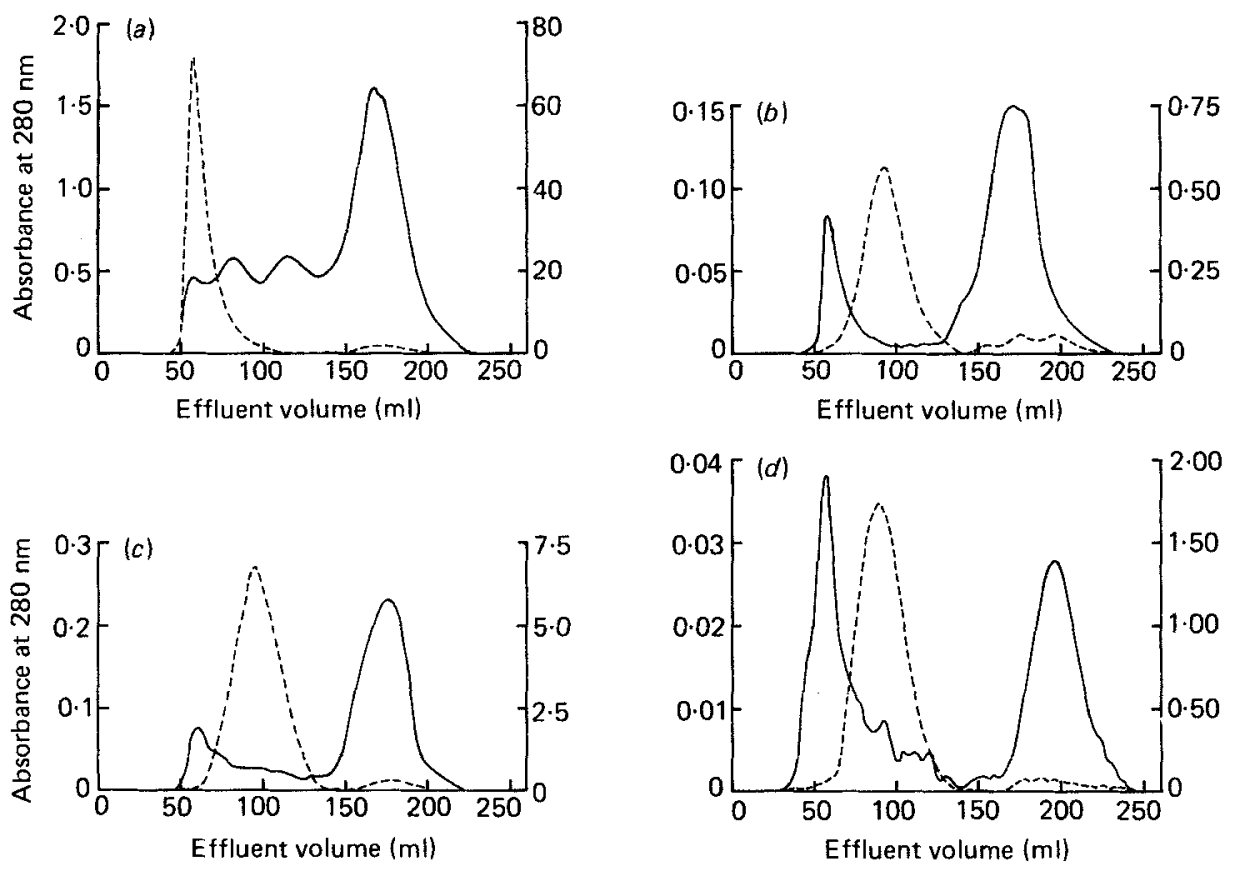

Fig. 2. Sephadex G-75 chromatography of soluble contents of the gastrointestinal tract of a kid, collected $1.5 \mathrm{~h}$ after giving a test feed of $\left[{ }^{3} \mathrm{H}\right]$ folic-acid-labelled goat's milk. Segments of the gut corresponding to the stomach, duodenum, jejunum and ileum were cannulated and washed out as described on p. 590 The samples were centrifuged and $5 \mathrm{ml}$ portions of the supernatant fractions analysed on a Sephadex G-75 column using a buffer containing $0.15 \mathrm{M}$-sodium chloride, $0.02 \mathrm{M}$-sodium phosphate, $\mathrm{pH} \mathrm{7.2,}$ 2-mercaptoethanol $(0.2 \mathrm{ml} / 1)$. (a) Stomach contents, $(b)$ duodenal contents, $(c)$ jejunal contents, $(d)$ ileal contents. $(---)$, [ $\left.{ }^{3} \mathrm{H}\right]$ folic acid; ( $(-$, absorbance at $280 \mathrm{~nm}$.

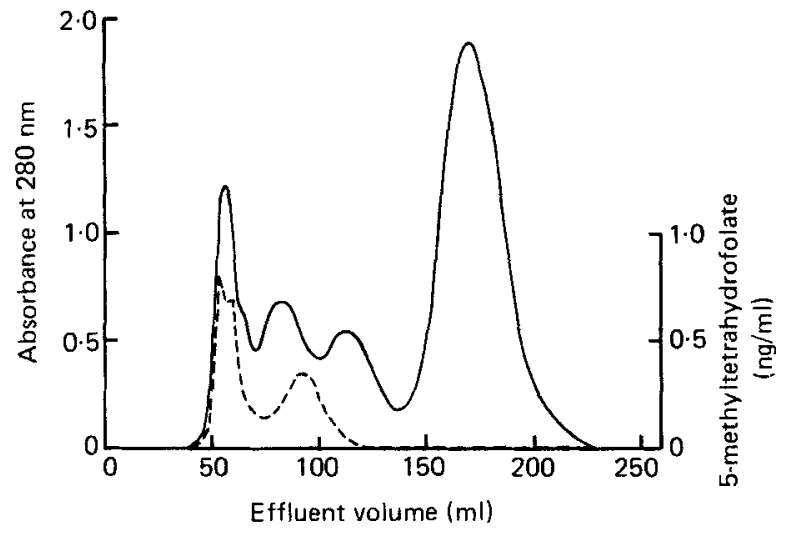

Fig. 3. Sephadex G-75 chromatography of raw goat's milk whey containing only endogenous folate. The goat's milk without added folic acid was freed from fat and micellar casein and analysed as described for labelled milk (Fig. 1). (-- - ), 5-Methyltetrahydrofolic acid; (-), absorbance at $280 \mathrm{~nm}$. 
Table 2. Recovery of free folate binder in the gut contents of kids given goat's milk containing folate-binding protein $(F B P)$ mainly unbound to folate

\begin{tabular}{|c|c|c|c|}
\hline $\begin{array}{l}\text { Kid no.... } \\
\text { Time after feeding (h).. }\end{array}$ & $\begin{array}{l}1 \\
0 \cdot 5\end{array}$ & $\begin{array}{l}2 \\
1\end{array}$ & $\begin{array}{l}3 \\
3 \cdot 5\end{array}$ \\
\hline Milk consumed (ml) & 300 & 250 & 190 \\
\hline $\begin{array}{l}\text { Capacity of FBP to bind added } \\
\text { folic acid in milk } \\
\text { consumed ( } \mu \text { g folic acid) }\end{array}$ & 50 & 42 & 32 \\
\hline $\begin{array}{l}\text { Folate-binding capacity } \\
\% \text { ) recovered in: }\end{array}$ & & & \\
\hline Stomach & $66 \cdot 5$ & $41 \cdot 3$ & $21 \cdot 3$ \\
\hline Duodenum & 0.02 & 0.30 & $0 \cdot 21$ \\
\hline Jejunum & 0.31 & $1 \cdot 20$ & 0.38 \\
\hline Ileum & 0.04 & $10 \cdot 7$ & 1.02 \\
\hline Total & 66.87 & $53 \cdot 5$ & 22.91 \\
\hline
\end{tabular}

dialysed, there was no measurable increase in the folate retained within the dialysis sacs. Thus in Expt 1 the binding proteins present in the ingested milk and recovered in gut contents were already fully saturated.

\section{Expt 2}

Form of endogenous protein-bound folate in goat's milk. The results of Sephadex G-75 chromatography of the whey prepared from goat's milk by centrifugation are shown in Fig. 3. The pattern of elution of protein as indicated by absorbance at $280 \mathrm{~nm}$ was similar to that found with $\left[{ }^{3} \mathrm{H}\right]$ folic acid-saturated milk (Fig. 1). However, the natural folate (5-methyltetrahydrofolate), as measured by microbiological assay, was distributed between two peaks corresponding to molecular weights of about 80000 and 38000 . No unbound folate was detected.

Excess FBC of milk and $F B C$ recovered in gut contents. Table 2 shows the total excess FBC of the milk consumed and the percentage FBC that was recovered in the soluble fraction from each segment of the gut of kids after $0.5,1$ and $3.5 \mathrm{~h}$. The results show that after $30 \mathrm{~min} 67 \%$ of the ingested FBC was recovered in the soluble gut contents and even after $3.5 \mathrm{~h} 23 \%$ survived. At $1 \mathrm{~h}$ after feeding, a higher proportion $(12 \%)$ of the $\mathrm{FBC}$ was found in the small intestine than at the earlier and later times.

\section{DISCUSSION}

FBP purified from goat's milk by affinity chromatography is known to have a molecular weight for the monomer of 37000-39000 (Rubinoff et al. 1977). However, in the present experiments, Sephadex-gel chromatography of whey prepared by centrifugation of goat's milk in which all the FBC was saturated with $\left[{ }^{3} \mathrm{H}\right]$ folate indicated a molecular weight in the region of 81000 . It seems very probable, therefore, that in the milk the binder is normally present in a polymerized form. The property of milk-binding proteins to show a reversible form of concentration-dependent aggregation is well known (Ford et al. 1969; Pedersen et al. 1980; Salter et al. 1981) and the presence of the folate binder apparently as a dimer is consistent with the much higher concentration of the protein in goat's milk (Ford et al. 1972) than in cow's milk, in which the protein demonstrates a molecular weight of $35000-38000$ (Ford et al. 1969; Salter et al. 1972). It is also probable that saturation of the protein with folate increased the tendency to aggregate (Pedersen et al. 1980). The molecular weight distribution of folate-binders, found here with fresh goat's milk containing only endogenous folate, fits into this scheme since two protein-bound folate peaks were found on Sephadex analysis, corresponding to molecular weights of approximately 80000 and 38000 . 
The survival of a considerable proportion of the $\left[{ }^{3} \mathrm{H}\right]$ folic acid $(34 \%$ after $1.5 \mathrm{~h})$ and of the unsaturated FBC $(21 \%$ after $3.5 \mathrm{~h})$ in the stomach contents indicates high resistance of the binding protein to gastric digestion. This is further supported by the results of Sephadex analysis of the soluble fraction of the gastric contents (which contained $93 \%$ of the total bound folate recovered in the stomach) which indicated that $\left[{ }^{3} \mathrm{H}\right]$ folic acid was bound to a protein of molecular weight 81000 , as found in centrifuged milk. Since the measured $\mathrm{pH}$ of the abomasal contents of the kids averaged $4 \cdot 0$, it is possible that some dissociation of bound folate occurred (Salter et al. 1981) in vivo, but that recombination with FBP occurred on adjustment of the $\mathrm{pH}$ value to $7 \cdot 2$ during column chromatography. Nevertheless, the protein must have survived in an active form. It must also have recombined with folate in the neutral environment of the small intestine, since no surplus binding capacity was detectable in the contents of the various segments of the small intestine.

In the duodenum and jejunum further small amounts $(0.25$ and $6.6 \%$ respectively) of the ingested folate were recovered in a bound form, $80 \%$ of this being in the soluble fraction of the digesta. The change in the molecular weight of the bound folate to about 39000 in samples from these segments of the intestine, which suggests dissociation of the FBP to the monomeric form, was presumably caused by the 10- to 100-fold dilution incurred by washing out the gut contents with saline. The relatively large percentage $(14.5 \%)$ of the ingested folate present in a bound form in the ileal contents may be important since the ileum is the major absorptive region of the gut for bound folate (Colman et al. 1981). Mucosal FBP have been demonstrated in rat intestine (Leslie \& Rowe, 1972), but the molecular species liberated from the brush border membrane with sodium dodecyl sulphate either had low molecular weights of 16000 or 24000 or were large species of molecular weight greater than 100000 . It would appear, therefore, that the $\left[{ }^{3} \mathrm{H}\right]$ folic acid remained bound to the milk FBP, rather than binding to any endogenous binders that may have been released from mucosal cell debris.

The percentage of free FBC recovered in the gut contents of the kids given goat's milk in which the FBP was mainly in the unbound form without added folate (Expt 2) paralleled the recovery of the $\left[{ }^{3} \mathrm{H}\right]$ folic acid-saturated milk FBP. Thus, after $1 \mathrm{~h} 41 \%$ of the ingested FBC was recovered in the stomach and $10.7 \%$ in the ileum, whilst the corresponding recoveries of $\left[{ }^{3} \mathrm{H}\right]$ folate-labelled FPB after $1.5 \mathrm{~h}$ were 37 and $14.5 \%$ respectively. This suggests that free and bound FPB are equally resistant to gastric and intestinal digestion.

Only a small percentage (about $12 \%$ ) of the $\left[{ }^{3} \mathrm{H}\right]$ folic acid recovered in the contents of the ileum was sedimented by centrifugation (Table 1). Presumably this fraction was composed mainly of mucosal cell debris and microbes and it may be inferred that little of the ingested folate was sequestered by folate-requiring micro-organisms due to the higher relative affinity of the milk FBP for folate (Salter t al. 1981). The results are thus consistent with in vitro experiments (Ford, 1974) that showed that the binding protein in goat's colostrum prevented uptake of folic acid by Lactobacillus bidifus, but suggest that the loss of folate-binding activity due to digestion with pepsin and trypsin observed in vitro was much less extensive in vivo. It is known that in other species (rat, pig), pepsin secretion is relatively low in the first 2-3 weeks after parturition (Aumaitre, 1972; Foltman et al. 1981) and that during the early stages of lactation milk contains a high level of trypsin inhibitor (Laskowski \& Laskowski, 1951). Such considerations may explain the present findings.

The implication of these results is that milk FBP has a considerable resistance to digestion in the stomach and upper small intestine and survives in an active form in the ileum, where it may be available to take part in folate absorption by interacting with receptors in the brush border of the mucosal cells. In the mature animal free folate was readily absorbed by an active process that was stimulated by glucose (Colman et al. 1981), whereas milk-bound folate uptake was not affected by glucose. It is possible that the main function of the milk FBP may be in assisting folate absorption in the neonatal period, possibly before the active 
transport system has fully developed. In this context the findings may be important in the feeding of neonatal infants, particularly when banked human milk or cow's milk formulas that have undergone some form of heat treatment are used, since pasteurization has been shown to cause changes in the folacin-binding characteristics of FBP (Gregory, 1982) even though others have shown only small effects on the ability of the binder to prevent folic acid uptake by gut bacteria (Ford et al. 1977).

The authors are grateful to Dr J. E. Ford for his continuing interest in this work and to Michael Walton and Sheila Neville for excellent technical assistance.

\section{REFERENCES}

Andrews, P. (1964). Biochemical Journal 91, 222-233.

Aumaitre, A. (1972). World Review of Animal Production 8 (3), 54-68.

Colman, N., Hettiarachchy, N. \& Herbert, V. (1981). Science 211, 1427-1429.

Foltman, B., Jensen, A. L., Lonblad, P., Smidt, E. \& Axelsen, N. H. (1981). Comparative Biochemistry and Physiology 68B, 9-13.

Ford, J. E. (1974). British Journal of Nutrition, 31, 243-257.

Ford, J. E., Knaggs, G. S., Salter, D. N. \& Scott, K. J. (1972). British Journal of Nutrition 27, 571-583.

Ford, J. E., Law, B. A., Marshall, V. M. E. \& Reiter, B. (1977). Journal of Pediatrics 90, 29-35.

Ford, J. E., Salter, D. N. \& Scott, K. J. (1969). Journal of Dairy Research 36, 435-446.

Ghitis, J. (1967). American Journal of Clinical Nutrition 20, 1-4.

Gregory, J. F. (1982). Journal of Nutrition 112, 1329-1338.

Hansen, S. I., Holm, I. \& Lyngbye, I. (1977). Scandinavian Journal of Clinical and Laboratory Investigation 37, $363-367$.

Herbert, V. (1961). Journal of Clinical Investigation 40, 81-91.

Kamen, B A. \& Caston, J. D. (1974). Journal of Biological Chemistry 250, 2203-2205.

Laskowski, M. \& Laskowski, M. (1951). Journal of Biological Chemistry 190, 563-573.

Leslie, G. I. \& Rowe, P. B. (1972). Biochemistry 11, 1696-1703.

Pedersen, T. B., Svendsen, I. B., Hansen, S. I., Holm, I. \& Lyngbye, I. (1980). Carlsberg Research Communications 45, 161-166.

Rothenberg, S. P. (1970). Proceedings of the Society for Experimental Biology and Medicine 133, 428-432.

Rubinoff, M., Schreiber, C. \& Waxman, S. (1977). Federation of European Biochemical Societies Letters 75, $244-248$.

Salter, D. N., Ford, J. E., Scott, K. J. \& Andrews, P. (1972). Federation of European Biochemical Societies Letters 20, 302-306.

Salter, D. N., Scott, K. J., Slade, H. \& Andrews, P. (1981). Biochemical Journal 193, 469-476.

Spector, R. (1977). Journal of Biological Chemistry 252, 3364-3370.

Waxman, S. (1977). In Advances in Nutritional Research vol. I, pp. 165-178 [H. H. Draper, editor]. New York: Plenum Publishing Corporation.

Waxman, S. \& Schreiber, C. (1973). Blood 42, 291-301.

Zamierowski, M. M. \& Wagner, C. (1977). Journal of Biological Chemistry 252, 933-938. 